COLD WAR FEMME 



\section{COLDWAR FEMME}

LESBIANISM, NATIONAL IDENTITY,

AND HOLLYWOOD CINEMA

\section{ROBERT J. CORBER}

Duke University Press

Durbam and London

2011 
(C) 2011 Duke University Press All rights reserved

Printed in the United States of America on acid-free paper @ Designed by Amy Ruth Buchanan Typeset in Carter \& Cone Galliard by Tseng Information Systems, Inc. Library of Congress Catalogingin-Publication Data appear on the last printed page of this book.

An earlier version of chapter 1 appeared in GLQ 11, no. 1 (2005). A portion of chapter 4 appeared in Camera Obscura 21, no. 2 (2006). 
For Kent

"right as rain" 
